Deleuzoguattarian Thought, the New Materialisms, and (Be)wild(ering) Pedagogies: A Conversation between Chantelle Gray, Delphi Carstens, Evelien Geerts, and Aragorn Eloff

\author{
Chantelle Gray \\ North-West University \\ Delphi Carstens \\ University of the Western Cape \\ Evelien Geerts \\ University of Birmingham \\ Aragorn Eloff \\ Independent Researcher
}

\title{
DOI: https://doi.org/10.1344/inmr.v2i1.33383
}

\section{Abstract}

This intra-view explores a number of productive junctions between contemporary Deleuzoguattarian and new materialist praxes via a series of questions and provocations. Productive tensions are explored via questions of epistemological, ontological, ethical, and political intra-sections as well as notions of difference, transversal contamination, ecosophical practices, diffraction, and, lastly, schizoanalysis. Various irruptions around biophilosophy, transduction, becomology, cartography, power relations, hyperobjects as events, individuation, as well as dyschronia and disorientation, take the discussion further into the wild pedagogical spaces that both praxes have in common.

\section{Keywords}

Deleuzoguattarian philosophy; new materialisms; (be)wild(ering) pedagogies; irruptions; schizoanalysis 
Riffing on the neologism intra-action-first introduced by Karen Barad in Meeting the Universe Halfway $(2007$, p. 33) and denoting "the mutual constitution of entangled agencies"- the notion of an intra-view suggests a different, queering, and more flowy take on the traditionally linear and chronological interview process. The inspiration behind this particular intra-view was a workshop on Félix Guattari's The Three Ecologies (2000) given at the Pedagogies in the Wild: The 2019 SA Deleuze \& Guattari studies conference at the University of the Western Cape, South Africa, in December 2019. In this intra-view, the conference organisers and workshop facilitators, Chantelle Gray (CG) and Aragorn Eloff (AE), were asked a series of introductory questions by Delphi Carstens (DC) and Evelien Geerts (EG) that explore Guattari's ecosophical ideas in the context of his work with Gilles Deleuze and the various ways in which their ideas have been enriched via encounters with new materialist and other immanence-focused theoretical-pedagogical lines of flight. These questions have themselves become entangled and diffracted (see Haraway, 1997 and Barad, 2007) through a series of responses, different sets of questions, and so-called "irruptions" or energy-filled provocations/disruptions in the margins of the intra-view that "exemplify and question linearity and normativity" (Koro-Ljungberg, 2015, p. xvii) by Delphi Carstens and Evelien Geerts-and eventually by all of the interviewersturned-interviewees and vice versa-relating to this special issue's wild pedagogical leitmotif. What is presented to the reader here, is thus an intra-view that not only has put these ideas of irruption and diffraction into action, but also is guided by Deleuze and Guattari's resistance against concretised methodologies through the form of individual and collective rhizomatic thinking-doings ${ }^{1}$.

\footnotetext{
${ }^{1}$ Also see the introduction of this special issue for this idea of thinking-doings.
} 


\section{What are some of the intellectual-political intersections between Deleuzoguattarian philosophy and contemporary new materialist thought?}

CG \& AE: Deleuze and Guattari's work, both individually and collectively is, in many ways, the most significant influence on new materialist thought, even if there is a notable lack of citation in this regard in much of the field. This has become increasingly clear as translations of the works of philosopher of science Gilbert Simondon (see e.g. The Mode of Existence of Technical Objects [2017] or the recently published Individuation in Light of Notions of Form and Information [2020]) have spread in the English-speaking world. It was his work that significantly influenced Deleuze's

DC: To my mind, Deleuze's discussions of differentiation and differenciation takes up the central problem of philosophy as it intersects with evolution, chaos theory, and molecular biology, namely, the problematic of endless variation vs. endless repetition (always the same thing, but never the same thing twice). Deleuze and Guattari's oft-repeated allusion to the symbiosis between the wasp and the orchid (see Sauvagnargues, 2019) is illustrative of how these authors have creatively taken up this problematic into their own processual bio/geo-philosophical assemblage.

The current COVID-19 crisis illustrates the importance of such a move; we cannot fully comprehend what is happening in our own bodies-let alone in our societies-without first apprehending the transcorporeal more-than-human biological/chemical/neuro-affective contact zones between individuals, non-human bodies, and the planetary ecology. Is it possible, in fact, to do any meaningful ontological or ethicopolitical work today without first apprehending, as these philosophers have done, the empirical claims made in fields like genetics, neurophysiology, evolutionary biology or biochemistry (see Carstens, 2019)?

discussions of processes of actualisation/individuation, the primacy of difference as well as the processes whereby the virtual contents of an idea are determined (differentiation) and that virtuality is actualised into distinguished parts (differenciation) and distributed; something that was initially best explored by researchers like Keith Ansell-Pearson and Manuel DeLanda (2006). Ansell-Pearson in Germinal Life (1999) for instance argues that Deleuze is primarily a biophilosopher posing complex questions around the unfolding of life that go far beyond the vitalist

CG \& AE: Biological research informs much of Deleuze and Guattari's philosophy and they continually remind us that the natural cannot be separated from the machinic. Guattari in fact renames 'environmental ecology' as 'machinic ecology' for the reason that "[c]osmic and human praxis has only ever been a question of machines" (2000, p. 66). Moreover, the final two chapters of Deleuze's Difference and Repetition (1994) are deeply influenced by philosopher of science Gilbert Simondon's theory of individuation, in which processes of individual and collective becoming emerge from pre-individual fields of intensity, situating difference as ontologically primary to identity, and process as prior to product. This challenge to the old hylomorphic schema, wherein matter is inert and in need of the transcendent imposition of form, has proven highly influential in the burgeoning field of philosophy of biology, with the ideas of Simondon, Deleuze and various interlocutors and fellow travellers-the pioneers of autopoiesis and enaction Francisco Varela and Humberto Maturana, for instance-increasingly reflected in work in developmental systems theory, emergence and similar fields in which matter is understood as pluripotent, dynamic, and bearing immanent, self-forming potential. 
DC: Transduction refers to Simondon's queering of individuation, which places emphasis on the pre-individual affects, virtualities, and potentialities that both constitute and determine the becomings that generate the multiplicity we mistakenly call the individual. Deleuze's provocation here is this: can we really say anything meaningful about individuals/individuation without considering the more-than-human physical, biological or psychic forces without which individuals cannot selfactualise or access collective or planetary processes?

appellation often foisted upon him, while DeLanda reminds us that Deleuze's work seeks to provide a metaphysics adequate to the new material sciences-those of complexity, chaos, emergence, and so forth.

These fields view heterogeneous arrangements of matter as full of morphogenetic potential (as described by both their phase spaces of behaviour as well as the underlying topological manifolds defining the tendencies towards maintenance or redistribution of these phase spaces), as involved in complex relationalities of reciprocal influence (and here Simondon's notion of transduction is particularly useful, especially via Deleuze's description of the method of dramatisation in Difference and Repetition (1994)), as inherently open and non-totalising, and as exhibiting non-linearities that entail a view of these arrangements (or 'agencyings,' to literalise the French term agencements typically translated as assemblages in Anglophone editions of Deleuze's work) as highly contingent.

In its preferencing of difference (and remember, Deleuze speaks of difference in itself, i.e., difference differing, as that by which the given is given, as opposed to mere diversity_the given) over identity, of multiplicities as inherently plural and heterogeneous (relating different to different) and process as primary (what Anne Sauvagnargues [2019, pp. 177-182] refers to as a "becomology" instead of an ontology), this is a profoundly challenging model of agency and subjectivity-especially in terms of its conviction that matter contains its own immanent possibilities for dynamism and change without any appeal to transcendence (Deleuze and Guattari's critique of

EG: 'Becomology' is a thought-provoking neologism that neatly captures Deleuze's more processual ontological worldview, Barad's (2007) agential realist ontologywhich deconstructs the divide between knower/known/knowledge process that is upheld in modern individualism-based Western metaphysics - that of the more Deleuzoguattarian new materialists, such as Rosi Braidotti (2013) and Elizabeth Grosz (2017), and of many Indigenous and Black feminist thinkers and activists that have always already spotlighted relational, environment-intertwined ontologies and epistemologies (see e.g. Ferreira da Silva, 2017; Hunt, 2014; Jackson, 2020; Smith, 2013; TallBear, 2014; Weheliye, 2014) but that have unfortunately not always been granted as much philosophical legitimacy (as also argued in for instance Todd, 2016). hylomorphism is perhaps most comprehensively expressed in A Thousand Plateaus [1987]), and it is here that Deleuze and Guattari's thought resonates strongly with the most salient spaces of exploration within the new 
materialisms. Between-and-becoming instead of here-there, this-that. As Deleuze and Guattari (1987) say in that most over-cited chapter on the rhizome: a river picks up speed in the middle.

EG: There are lots of entanglements between Deleuzoguattarian philosophy and contemporary new materialist thought to be (re)discovered and diffracted,

DC: New materialist and Deleuzoguattarian philosophies share several core pedagogical provocations and onto-ethical premises, which I have explored in more detail elsewhere (see Carstens, 2019). The core of these shared provocations are as follows: "(1) that we need to exhume materialities lost in a decades-long fetishization of texts and discourses by the so-called linguistic or cultural turn; (2) that education needs to be more attentive to developments in the contemporary life sciences; (3) that matter has some form of agency; and (4) that entities do not precede their relations but rather emerge from them" (p. 144). specifically when it comes to the creative-critical revisioning of difference-as-differing, ontology, (inter)subjectivity, and agency. New materialist thinkers such as Braidotti (2013), Grosz (2017), and Erin Manning (2009) have used the Deleuzoguattarian onto-epistemological framework to rethink how we are situated (with)in the world while calling for a feminist, posthumanist take on the Deleuzoguattarian conceptual apparatus to better analyse today's Zeitgeist. Especially Braidotti's work can be read as a continuation of the Deleuzoguattarian philosophical project-or, more aptly put, critical-creative ways of thinking, as 'project' comes across as a way too linear, systematic way of doing philosophy.

If we were to briefly provide a critical cartographical sketch of contemporary new materialist thought-which, by the way, is quite tricky, as there are many new materialisms out there that were nourished by different philosophical materialist, but also feminist, traditions - then we could say that the idea of neo-materialist thinking was first coined by Braidotti (1991) and philosopher Manuel DeLanda (1996) in the 1990s. Braidotti describes the enterprise as follows: New materialist thinking is "a method, a conceptual frame and a political stand, which refuses the linguistic paradigm, stressing instead the concrete yet complex materiality of bodies immersed in social relations of power" (Braidotti in Dolphijn and Van der Tuin, 2012, p. 21).

EG: It is important to pause for a second here, let an irruption arise, and think about the ways in which critical theorists tend to construct genealogies of philosophical concepts and cartographies (Braidotti, 2011) of strands of thought: Framing, conceptualising, and mapping out phenomena-whether conceptual, empirical, or a mix of both-are never innocent acts and processes.

These epistemological knowledge-creating processes involve a certain kind of world-making and are thus always also at least partially ontological in nature. These onto-epistemological processes should be taken into account when mapping out contemporary new materialisms and their interlinked assemblages (also see Geerts \& Carstens, 2019). 
AE \& CG: Rendered in French as pouvoir and puissance respectively, potestas and potentia, which come to us from Spinoza, are subsumed into the term 'power' in English, eliding their fundamental difference. For Deleuze, along with fellow Spinozists like Antonio Negri and Michael Hardt, potestas refers to an organised, transcendent form of power whereas potentia refers to our immanent force or capacity to act. Politically, potestas can be seen as the shutting down of possibility entailed by the State, Hobbesian or otherwise, with its monopoly on violence, authority and coercion. Against the State and also prior to it, potentia is the infinite reserve of capacity and possibility produced by expanding our collective, revolutionary powers of acting-the real strength of the multitude or the war machine.
It is this emphasis on situatedness, immanence, and embodiment that matters here: Like Deleuzoguattarian thought, new materialist theories focus on the world and theorising from within the world to provide a post-poststructuralist analysis. Highlighting how human-but also nonhuman, more-than-human, and dehumanisedbodies are located within intricate webs of power as potestas and potentia, is central to new materialist theorising. Power relations do not only paralyse subjects but also provide them with contours and parameters to operate within and fight against. Apart from thus accepting the importance of analysing as well as resisting bio-necropolitical webs of power relations inherent to the encounters and institutions of power we are all a part of, new materialist philosophies also aim at deconstructing various binary-fuelled systems, such as Western anthropocentrism, androcentrism, and human exceptionalism, to reveal a caring for all things of matter. Nature, in both new materialist and Deleuzoguattarian onto-epistemologies, is all that is material-which also includes the cultural and the digital. Regarded as demonstrating agential capacities, nature is put at the forefront of new materialist as well as Deleuzoguattarian theorising, which gives new materialist thought what I would call a critical ecological touch, in addition to the ethico-political characteristics that reveal themselves because of the new materialisms' interest in relations of mattering and power.

New materialist philosophies, such as those of Braidotti (2013), Barad (2007), but also Mel Chen (2012), Stacy Alaimo (2016), Donna Haraway (2016), Alexis Shotwell (2016), María Puig de la Bellacasa (2017), and many others, are thus brought together by a belief that every little piece of matter matters, and they can therefore can be read as critiques of the commodification, exploitation, and total destruction of living matter in all of its differing forms-something that corresponds well with Deleuze and Guattari's critique of capitalist extractivism, as touched upon in for instance AntiOedipus (1983) and its sequel, A Thousand Plateaus (1987). 
DC: Deleuze and Guattari in fact suggest that capitalism has naturalised the artificial, decoding individual and collective flows along with ecosystem and biological production flows, while recoding them around the body of capital-money. Capitalism is infinitely flexible, "always ready to widen its own limits so as to add a new axiom to a previously saturated system" in which everything is monetised and "money and the market" act as its only "true police" (1983, p. 259). As a giant over-coding and regulating machine, capitalism's singular purpose is to overcome all "limits to growth" as it undertakes a process of "terraformation" (Cooper, 2008, pp. 41-42). While it plunders and lays waste to the body of the Earth (to convert it all into capital-money), capitalism forestalls resistance by atomising the collective/communal will, collapsing it into hierarchical power struggles and competitions between individual desires. Capitalism understands only too well that desire is a world-shaping force from which it means to extort surplus value; a force it has added to its axiom, while turning it against individuals and collectives.

Resistance against the terraforming machine of capital will only be possible if we learn to build new subjectivities that recognise that the individual is not the paragon of truth, that thought is not grounded in identity or representation, but generated out of difference, that desire is not individual but multiple. Our task, as Deleuze and Guattari (1983) see it, is to decode the unconscious processes of desire and explore alternative ways in which desires might be organised. Their immanent transversal philosophy challenges the centrality of any one particular domain of meaning-making, identity or even order of materiality and immateriality.

EG: When the notion of geopower is linked to the current entangled Anthropocene and capitalist extractivism crises, questions of geopolitical nature immediately arise: are we really in all of this together in an equal manner? Will the COVID-19 crisis for instance really provoke a 'Great Reset' of global capitalist systems and structures, or will this socalled 'Fourth Industrial Revolution' merely end up sharpening pre-existing global inequalities?

DC: Individuality, culture, and history have a radical inhuman outside to them. The desire for individual and political gratification always resists this outside yet forgets how power, sex, race, and oppression move through the earth into individuals, societies, art, and politics and back into the body of the earth via collectivized desires such as capitalist extraction and progress narratives. The work of Deleuze and Guattari and those of feminist new materialists like Grosz (2017) and Elizabeth Povinelli (2016) provoke us into thinking about how geosocial formations come into being and persist. Can we really make any theoretical claims without first considering how notions of individual and collective autonomy are both informed and altered by such geosocial power relations and to the spectre of the inhuman/more-than-human outside that hangs over them?

In this sense, I think that many feminist new materialists, although they might not align themselves with Deleuzoguattarian thought, are nonetheless on the same page in 
their critique of capitalism. In this critique, both feminist new materialists and Deleuzoguattarians are aligned in their merger of neo-Marxist and/or neo-materialist perspectives, their foregrounding of minoritarian struggles, their interest in geopower, their turns toward evolutionary theory, and their queering of psychoanalysis.

EG: All four of us seem to be on the same page when claiming that there are many resonances between Deleuzoguattarian philosophy and new materialisms-although it is also fair to say that many current-day thinkers that are regarded as new materialist build on a different genealogy than Deleuze and Guattari's philosophy (and indeed do not cite Deleuze or Guattari): Haraway and Barad, for instance, tend to distance themselves from Deleuzoguattarian philosophy, and their oeuvres moreover appear to be much more rooted in the Anglo-American enterprise of feminist science studies and Foucauldian understandings of (bio)power, the body, and power/knowledge. Barad's (2007) agential realism moreover has Levinasian-Derridean touches to it if we were to examine Barad's interpretation of alterity and the ethical more closely. Already

EG: Both Levinas (2015) and Derrida (1994) are preoccupied with finding a more positive conceptualization of alterity and, hence, more ethico-political interpretations of justice: Treating justice as a regulative, transcendent ideal yet-to-come, however, their philosophies differ from Barad's, as the latter emphasizes the immanent, worldly contours of justice.

hinting at Levinasian-Derridean philosophy in Meeting the Universe Halfway (2007), Barad in a later article (2010) suggests that ethico-political response-ability is not only woven into the world but also depends on an agential realist understanding of the relational connections between beings, rather than subjects and objects with identities-as-differing. Or as Barad (2010) put it in said article:

Entanglements are relations of obligation-being bound to the otherenfolded traces of othering. Othering, the constitution of an "Other," entails an indebtedness to the 'Other,' who is irreducibly and materially bound to, threaded through, the 'self' - a diffraction/dispersion of identity. 'Otherness' is an entangled relation of difference (différance). . .. Crucially, there is no getting away from ethics on this account of mattering. (p. 265)

This particular genealogy that focuses on a pre-existing relationality between all that is that can-or also could not-materialise itself on the basis of recognising that the self is never a 'self' without the Other is definitely different from Deleuzoguattarian affirmation. An approach that is also for instance central in Braidotti's Deleuzoguattarian new materialist philosophy that, as she also writes it in an article 
from 2006, "takes as the point of reference bios-zoē power defined as the non-human, vitalistic, or post-anthropocentric dimension of subjectivity" (p. 3). In a way, Braidotti and other more Deleuzoguattarian new materialists, such as the already referred to Grosz, offer us an affirmative way out of the recognition conundrum that is so central to Levinasian-Derridean and also Baradian philosophy: The gist here is that the Other needs to be recognised by the subject as their master for the ethical moment to happen-and in Levinas' philosophy, there is consequently space to also theorise moments of misrecognition and the violence these have engendered. In a Baradian agential realist model, that focuses on complete relational indebtedness, however, misrecognition almost appears to be theoretically impossible...

What about the relevance of The Three Ecologies (2000) to contemporary new materialist thought? Could we for instance reread the book as an ethico-political manifesto?

AE \& CG: In The Three Ecologies (2000), Guattari addresses many socio-political problems that we are grappling with today, for example techno-scientific innovations and their multiple, sometimes unexpected, consequences; the modulation-and often retrogression - of human modes of living which, of course, has a direct impact on nonhuman modes of being (frequently disastrous ones!); the rise of nationality which, in its current manifestations, has dire implications for migrants with its exacerbated racist machinery; the homogenising function of media and, now, social media. The list goes on. What is important about this text for new materialist thought, we would say, is that it recognises the entanglement of environmental ecology, social ecology, and mental ecology, taking into consideration not only the macro instantiations of these, but also the molecular domains of affect and desire.

For Guattari, new ecosophical practices must take into account many tangled and heterogeneous singularities — even repressed desires - to counter the ever-expanding and totalising agenda, and grip, of capitalism. Guattari (2000) proposes, then, that we develop a transversal conception of subjectivity which allows for an interface between what he calls existential territories or the actual (finite personal worlds) and incorporeal universes or the virtual (the infinite, non-dimensioned, non-coordinated, trans-sensible world). This final emphasis is of particular importance to the new materialism because if we cannot think the virtual, we limit our understanding of materiality for there is 
always something which exceeds that which is actualised. This is the magic of Deleuze and Guattari's philosophy, isn't it?

DC: Regarding the manifesto question, I think that Guattari certainly puts together a declaration of intentions that he intended for readers to apply to their immediate contexts with the aim of effectuating real social change, so, in this sense, it is a manifesto. On the other hand, all of Guattari's work reads a bit like a manifesto but exceeds the purposes of the latter because he also tends to develop a very philosophical project. Still, I think The Three Ecologies (2000) has much to offer contemporary new materialisms, especially when it comes to its holistic approach to life and the fine balance between society and the forms of societal alienation we are seeing, plus the ecological crises of our times and mental ecology, including the proliferation of mental illness.

What does the notion of diffraction mean, philosophically speaking? Would it be possible to interpret Deleuzoguattarian schizoanalysis as diffraction-in-action?

EG: As also argued elsewhere (Geerts \& Van der Tuin, 2016), ${ }^{2}$ the idea of diffraction, seen from a critical theoretical point of view, is closely linked to the project of feminist science studies, and the work of Haraway and Barad in particular. Rooted in Haraway's (1997) take on Trinh Minh-ha's (1997) critique of an apartheid-focused conceptualisation of identity-as-wholly-Other, Barad's (2007) understanding of diffraction is almost a performance of diffractive reading, as both the ideas of diffraction as thinking identity differently (Minh-ha) and diffraction as transcending the traditional epistemological practice of reflection (Haraway) are included in it. As a methodology, diffractive reading and theorising is meant to be a more accountable, affirmative way of engaging with ideas, concepts, theories, while respecting the differences between these ideas, concepts, and theories.

\footnotetext{
${ }^{2}$ This particular New Materialisms Almanac entry has been republished in this special issue.
} 
CG \& AE: For Deleuze and Guattari, schizoanalysis offers an alternative method to psychoanalysis. It is a cartographic practice, a process of "plotting a chart of semiotic regimes" (Deleuze, 2006, p. 13) that are historical, pathological, despotic, or whatever, and function in complex ways related to power-not the nature of power but, following Foucault, lines along which power exerts itself and why it does so in particular ways and in specific places. This is important for Deleuze and Guattari because they recognise that regimes of signs and their related power mechanisms machine subjectivity in specific ways. In their study of capitalism and psychiatry, they show how flows of intensities become machined and directed to work for the ends of capitalism. Schizoanalysis is a practice aimed at releasing these intensities again-literally allowing life to flow through us more freely. It is, in essence, a healing and liberating practice. If we think of diffraction as an interference, a redirection of energies, then yes, we could think of it as diffraction-in-action but thinking only of it in terms of diffraction would detract from the complexity of this practice.

AE \& CG: Prefiguring the dominant view in the contemporary neurosciences, Deleuze and Guattari famously observe near the beginning of $A$ Thousand Plateaus that "many people have a tree growing in their heads, but the brain itself is much more a grass than a tree" (Deleuze \& Guattari, 1987, p. 36). Far from the arboreal model of thinking, with its neat categories, rote repetitions, and predefined relations between terms, rhizomatic thought entails the conjugation of the singular points of disparate series - the defining of an Idea or problematic field-to see what emerges. We learn to swim not by reflection, but through the shock of the icy water, combining the distinctive points of our bodies with those of the waves as we dive into the ocean, bringing together multiple heterogeneous systems in a creative process of learning without exhausting the infinite spaces of real possibility immanent to these systems.

EG: Looking at it in the foregoing manner, diffractive thinking probably resonates more with Deleuzoguattarian rhizomatic thought than with the praxis of schizoanalysis. At the same time, one could of course also interpret schizoanalysis as a diffractive engagement with the French, mostly Lacanian, tradition of psychoanalysis, Foucauldian ideas about power and fascism, and the Hegelian negative conceptualisation of difference.

DC: For Deleuze and Guattari, continuous diffraction is a given; although they use terms such as transversal communication and creative involution, while referring frequently to co-evolution (as in their favourite example of the symbiotic merger between the pollinating wasp and the orchid)! They problematise the whole notion of either/or statements (binary logics) as well as singular representations of the reality. 
In the "Rhizome" section of $A$ Thousand Plateaus (1987, p. 11), for instance, they counsel us to look to "the wisdom of the plants: even when they have roots, there is always an outside where they form a rhizome with something else-with the wind, an animal, human beings," etc. And so it is with everything in the universe. There is nothing singular in the world, least of all an individual. Everything-whether rock, computer code, bacterium, cosmic ray, capitalism, plant or human forms an assemblage with a multitude of other things and is entangled in transversal relations that completely scramble singular genealogical trees.

On the simplest level of this rhizomatic/schizophrenic/diffractive convergence, Deleuze and Guattari (1987, p. 4) point out that all assemblages (whether we are talking about individual humans, rocks, plants or meaningmaking assemblages like new materialism, science fiction, sociology, organic chemistry, or what have you) face (at least) two sides: that of order and that of radical intensity. Their work is full of warnings and caveats about the dangers of leaning too heavily on one side of the assemblage. Deleuze and Guattari repeatedly warn us that ignoring the orderly and cohesive can lead to botched or frozen meaning-making

DC: Unfortunately, as Katherine Hayles (2017, p. 71) also points out, a lot of new materialist philosophy has tended to lean too heavily on the intensive desire-driven side of things, while eradicating from its figurations "the necessary other side of the story, the forces of cohesion, encapsulation and level-specific dynamics characteristic of living beings."

EG: This most likely can be brought back to the vitalist philosophical origins - which is not to be confused with so-called Lebensphilosophienof many current-day new materialisms: Thinkers such as Braidotti (2013) but also Grosz (2017) and Jane Bennett (2010) rely on an affirmative conceptualisation of energydriven matter. assemblages (while the reverse is just as true), which is something they develop extensively in the "Body without organs" section of $A$ Thousand Plateaus (1987).

Freud, whom Deleuze and Guattari playfully diffract via Marx, and vice versa, was positively haunted by the radical afterwardness of meaning-making. Deleuze and Guattari are haunted by something analogous. While resisting Freud's ahistorical interpretation of desire, they simultaneously resist Marx' ardent historicism, which failed to incorporate collective desire. For Deleuze and Guattari, there is something radically belated and uncanny about our desire to attempt to create meaning (via Marx' Hegelian dialectic or tripartite division of history, for instance), which means that we need to come at materiality from all sorts of angles, intensive, orderly, aesthetic, scientific, and, and ... while realising that thought and matter are always "connected, caught up with one another" (1987, p. 10). 
Simultaneously, via their schizoanalytic praxis, Deleuze and Guattari are building a kind of therapeutic healing practice for liberating and exploring alternative organisations of desire that resist the deadening facticity of capitalism and its ruinous spectre of individuality.

CG \& AE: Deleuze and Guattari develop schizoanalytic praxis as a healing practice of desire. It thus replaces the then dominant practice concerned with libido, namely psychoanalysis. Whereas psychoanalysis subjects desire (libido) to the transcendent and universal form of Oedipus, Deleuze and Guattari-as in all their other projects - aim to think of desire more immanently, albeit machined, as a process of "discovering for every case the nature of the libidinal investments of the social field, their possible internal conflicts, their relationships with the preconscious investments of the same field" (1983, p. 382). Schizoanalytic praxis is therefore a defamiliarising and resingularising practice along molecular lines-in the cracks and fissures of molar life-aimed not so much at a particular goal, but at experimentation which, in turn, allows for the production of the new. Guattari, in Chaosmosis (1995, p. 12) explains it as follows: "A long time ago I renounced the Conscious-Unconscious dualism of the Freudian topoi and all the Manichean oppositions correlative to Oedipal triangulation and to the castration complex. I opted for an Unconscious superposing multiple strata of subjectivation, heterogeneous strata of variable extension and consistency. Thus a more 'schizo' Unconscious, one liberated from familial shackles, turned more towards actual praxis than towards fixations on, and regressions to, the past."

What is the pedagogical importance of The Three Ecologies (2000) \& Deleuzoguattarian thought?

CG \& AE: The plethora of secondary literature on pedagogy and Guattari and Deleuze attests to the importance of these transversal lines far better than what we can easily summarise here. The Three Ecologies (Guattari, 2000) speaks to something we think should be the very foundation of contemporary pedagogy, namely healing practices, as they pertain to forms of sociality, mental and emotional wellbeing, and ecological balance, as well as the deep interconnections between these ecologies. Guattari's psychoanalytic background was of huge importance to the duo's work, especially his focus on subject groups; that is, group formations that allow people to work horizontally and experience practices of power-and not only power against, for example hierarchies or binary thought processes, but power in its positive iteration, so power to be creative together, to produce new forms of organisation and so on. These are healing practices because they resist forms of domination, something that is hugely prevalent in schools and academia alike.

What would it look like to change the forms of social organisation in academia where management is not separate from the 'everyone else,' where support staff are treated with the same respect as professors, where students are included in curricula development, where ecological health is integral to all classroom practices, just as 
mental health is? Instead, we more often than not have the few making decisions for the many, themselves slave to a machinery so succumbed to neoliberal ideals that pedagogy lags far behind economic and related interests.

Guattari, and Deleuze, might ask us to consider how we can change our values of desire to seek social and aesthetic profitability over economic ones. The importance of this text-The Three Ecologies - is thus its guidance towards producing new forms of subjectivity from which creative autonomy, individual and collective power, and joy can flow. This seems to be a worthwhile pedagogical endeavour!

Given the transversal focus of Deleuzoguattarian philosophy, how can we push for dialogues across disciplines of knowledge at universities in order to foster ecological pedagogical practices-especially those type of practices that help generate appropriate pedagogical responses and

DC: Hyperobjects are eventful. According to Deleuze and Guattari (1987), failing to account for the differential scales and speeds at which events occur means that we are unlikely to survive them.

So, unless we are able to comprehend and become accountable to the differential inhuman scales and speeds of the hyberobject/event called the Anthropocene, as Povinelli (2016) warns, the multiscalar/multi-temporal assemblage we call the biosphere will simply become "something that will potentially extinguish the [human] world and the way we exist in it" p. 56). The provocation here is this: can a monotheistic/anthropocentric worldview apprehend the contours of an eventful hyperobject? Neither Povinelli or Deleuze and Guattari seem to think so. Instead, these thinkers suggest that only an animist worldview, which can acknowledge ways of existing other than our own (and thereby extend becoming and actualization to all forms of existence), will suffice to see us out of this mess. stratagems to the Anthropocene?

DC: The stable climatological conditions of the Holocene have been terminated by the Anthropocene. Agriculture, civilisation, and industry developed and flourished under circumstances that no longer hold; it is uncertain how much longer capitalism, no matter how sorcerous, will be able to hold back the inevitable. Under such dire circumstances, the task of pedagogy involves more than mere chronicling. If our purpose is to forge a real, 'worldly' justice-to-come, then as pedagogues

we will need to find more inclusive and tangible ways of imagining a future that is not bound up in destructive fantasies of progress and human mastery that have led us into this mess. I think Timothy Morton's term hyperobject (2018) best describes the Anthropocene, which is happening at so many different levels and across so many different scales that it is, in effect, thoroughly bewildering and hard to grasp.

If there is to be any future, however, pedagogy will need to find ways of reaching into 
this atemporal multi-scalar tangle. Deleuze and Guattari show us how more-thanhuman natural histories can be made alive to human cognitive and cultural practices. By utilising their schizoanalytical and transversal strategems, we can find ways of stimulating the imaginative capacity of our students to dream up different and more ethically inclusive futures that are immanent to the networks and natural histories of life that sustain and nurture us.

In one of my favourite pedagogical scenes in A Thousand Plateaus (1987), Deleuze and Guattari mobilise a fictional pedagogue, Professor Challenger, to generate a multi-disciplinary pedagogy of bewilderment. A similar scene occurs in Bram Stoker's Dracula (1897) via the fictional pedagogue Dr Van Helsing. These pedagogical scenes illustrate the importance of thinking, teaching, and researching about matter and materiality-and, indeed, about what it means to be human in a more-than-human world-by taking onboard the uncanny, the spectral, and the affective. The transversal, trans-disciplinary pedagogies imagined in these scenes not only merge insights from various (and even apparently contradictory) disciplines, but also reveal that a multi-disciplinary pedagogy needs to play up the central trope of the minor literature of science fiction, namely, cognitive estrangement by literally 'making strange.' Pedagogy needs to provoke the mind of learners to interpret and create by thinking outside of the box. The unthinkable alternative is a pedagogy of rote-learning, confined to reductive disciplinary boundaries that slavishly mimes whatever disciplinary-specific epistemology is currently in vogue. This kind of pedagogy is going nowhere. It is only by trespassing, hopping fences, and forging tangled interdisciplinary pathways across multiple disciplines and subject fields that pedagogy can hope to plot escape routes from the major crises of our era.

Deleuze and Guattari's transversal approach mobilises perspectives from outside of philosophy to come to less restrictive understandings of philosophy. Pedagogues need to do the same; marshalling perspectives from beyond whatever discipline or field they might be operating within to enable themselves and their students to come to new modes of awareness. Mobilising a transversal/transdisciplinary outside to any specific discipline is an absolute necessity in an age that is becoming increasingly equivocal and difficult to determine. 
How do we take seriously Deleuze and Guattari's ideas of transversal contaminations, as articulated in A Thousand Plateaus (1987), between widely divergent realms of knowledge? And how do we use these to facilitate a pedagogy that is able to practice hauntology?

DC: The hauntological project alerts us to the fact that capitalism has engendered an age of dyschronia when time is out of joint. Getting to grips with dyschronia means mobilising the spectral and uncanny; and the Deleuzoguattarian praxis is all about learning the uncanny (see Ramey, 2013).
DC: Dyschronia reminds me that the Anthropocene is powered by the homogenizing anthropocentric spatio-temporality of agricultural time, which has "sucked all lifeforms into it like a vacuum cleaner" (Morton, 2018, p. 77). Agriculture is the demon-engine of civilisation and its latest iteration: capitalism. Industrial agriculture has engendered systems of multispecies forced labour in which the divergent generation times of plants, animals, humans, and microbes have been vastly altered and homogenised to serve the regulated time of economised productivity (Haraway, 2016). The Deleuzoguattarian provocation here is to free ourselves from the domination of human time as the sole apparatus of meaningmaking. We need to take stock of their claims (see 1983 and 1987) that our ways of apprehending time are vastly out of joint and that there are multiple more-than-human temporal formats that we need to urgently take onto-ethical stock of.

EG: When I hear the notion of hauntology, I immediately am reminded of the oeuvre of Derrida and his Specters of Marx (1994) and the new materialist takes on conceptualizations of temporality, the haunting ghosts of injustice, and the pedagogical. Whereas Derrida mostly uses the idea of hauntology in reference to the continued value of Marxist thought for continental critical theory, Haraway (2016) and Barad (2010 and 2019) each engage with the hauntological to come up with an ethicopolitics of the present that teaches us to not defer our responsibilities to future times, but to, as Haraway (2016) so neatly puts it, 'stay with the trouble' instead and work through the nitty-gritty. Ghosts of the past, but also of the present and future, need to be reckoned with, according to these two new materialists, and it is in this affirmative reckoning and working through that I see a link with Deleuze's and Guattari's more affirmative take on the hauntological. 
DC: By orientating itself around the uncanny, the Deleuzoguattarian project moreover can steer us through these troubled times of change, haunted by the ghosts of displacement and extinction, toward more affirmative educational spaces. Creating such learning spaces, however, is no simple task; it requires that we trouble reductive anthropocentric narratives of control and mastery by
EG: The notion of (dis)orientation here reminds me of Sara Ahmed's (2006, pp. 5-6) phenomenological conceptualisation of feeling disoriented: "In order to become orientated, you might suppose that we must first experience disorientation. [...] When we experience disorientation, we might notice orientation as something we do not have." Disorientation is revealed as resembling feeling lost in space-no longer having a space in place - and in time-a temporalities-based framework that only really starts making sense once it has been brutally halted.

DC: The pedagogical importance of bewilderment is what drew Deleuze and Guattari to queering Freud, who was obsessed with the ways in which the "conscious self fictionalises itself in belated relation to the materiality of events" (Carstens, 2020, p. 78). For these philosophers, the bewildering nature of cognition does not imply that "reality is unknowable or unteachable"; rather that cognitive disorientation can be made productive by highlighting that mastery is impossible and that "no single epistemological stratagem (such as reductive science, for example) will completely suffice for knowing (or teaching about) materiality" ( $p$. 78).

embracing disorientation and bewilderment. Only by bewildering ourselves and our students, only by bringing different categories of thought, action, affect and aesthetics, as well as different orders of meaning-making into productive conversation with one another in our classrooms and research practices will we be able to practice a genuinely posthuman hauntology.

How can we use Deleuze and Guattari for the implementation of 'minor' practices in higher education despite the encroachment of neoliberal practices and standards in classrooms?

DC: My own work centres around the importance of the aesthetic register of the uncanny in an equivocal age-the Anthropocene-that is increasingly spectral, unhomely, defamiliarising, and ambiguous. The big question for me is how education can break free from the shackles of what Mark Fisher (2009) calls capitalist realism and also from the bonds of human exceptionalism, both of which have come to exert such a poisoned stranglehold over all forms of social reproduction, including education. While human exceptionalism focuses on the reasoned and orderly nature of particular Enlightenment expressions of the human, capitalist realism has been all about combining the arrogant certitude of anthropocentric humanist perspectives with highly speculative and risky endeavours. For a long time, philosophy was overly 
concerned with contradiction (e.g., between the orderly and speculative, the human and the non-human, etc.). This was the Marxist response to capitalism (i.e., that it would self-destruct due to its internal contradictions, such as its perpetual boom and bust cycles); to which Deleuze and Guattari (1983) infamously remarked that nothing ever died from contradiction-least of all capitalism!

I think that it is vitally important for pedagogy to keep exploring that which remains radically outside and otherwise to the neoliberal mainstream by playing up the uncanny, the ambiguous, the contradictory, the difficult to determine, the bewildering, and the uncertain. Here, I think that it is extremely important to note the nuances inherent in the term speculative. Capitalist logics of speculation and neoliberal speculative pedagogies (ones that capitalise, valorise, and seek economic returns on knowledge and learning), for instance, are not the same as "audacious pedagogies of speculative fabulation" (Carstens, 2020, p. 75).

EG: Deleuzoguattarian pedagogy strongly evokes the anticapitalist critical pedagogies of Theodor Adorno and Max Horkheimer (1997), Paulo Freire (2006), and bell hooks (1994)-materialist thinkers that all have responded to the incessant commodification and corporatisation of higher education and the classroom tout court. Deleuze and Guattari might have brought the more-than-human, the (be)wild(ering), and the pedagogical closer together; the foregoing thinkers also critically tackled capitalism's internal contradictions by tackling the latter's - often quite literaldehumanising effects by emphasising education's consciousness-raising, liberating, and relational potential.

The kind of pedagogy that Deleuze and Guattari advocate "embraces uncomfortable yet productive tensions," by weaving together "a diversity of signals and affective regimes" from the minor sciences and arts in order to generate portals "between the scientific/technological and the mystical, the heterogenous and the singular, the human and the non-human, the fixed and the fluid" (p. 77). Pedagogy needs to jump the arbitrary fences erected between disciplines of knowledge and orders of meaningmaking. It also needs to accept, as a central premise, that the world remains a morethan-human world that lies tantalisingly beyond our human-all-too-human grasp. Knowledge and learning should bewilder, not make us secure in our anthropocentric certitudes! No matter how much science, economics, or philosophy (or any other discipline) progresses, it will never uncover the whole of the world. This does not, however, mean that the majoritarian regimes of neoliberal capitalism are not hell-bent on cracking open every corner the world, but it does mean that transversal minor practices (minor science, minor art, minor literature, minor philosophy, minoritarian becomings, etc.) offer productive pathways of aesthetic resistance to capitalism's 
deterritorialising/reterritorialising speculative logics of extraction and economisation. It is after all by mobilising the uncanniness of minoritarian aesthetics that Deleuze and Guattari are able to mobilise pedagogical experiments that resist the uncanny worldannihilating, future-eating, disjunctions and agitations of neoliberal capitalism!

\section{Acknowledgements}

Special thanks go out to this section's editors, Melisse Vroegindeweij and Jacky Barreiro.

\section{Bibliography}

Adorno, Theodor W. \& Horkheimer, Max (1997). Dialectic of enlightenment. (J. Cumming, Trans.). Verso.

Ahmed, Sara (2006). Queer phenomenology: Orientations, objects, others. Duke University Press.

Alaimo, Stacy (2016). Exposed: Environmental politics and pleasures in posthuman times. University of Minnesota Press.

Ansell-Pearson, Keith (1999). Germinal life: The difference and repetition of Deleuze. Routledge.

Barad, Karen (2007). Meeting the universe halfway: Quantum physics and the entanglement of matter and meaning. Duke University Press.

Barad, Karen (2010). Quantum entanglements and hauntological relations of inheritance: Dis/continuities, spacetime enfoldings, and justice-to-come. Derrida today, 3(2), 240-268. https://doi.org/10.3366/drt.2010.0206.

Barad, Karen (2019). After the end of the world: Entangled nuclear colonialisms, matters of force, and the material force of justice. Theory \& Event, 22(3), 524-550. Retrieved from https://muse.jhu.edu/article/729449\#info wrap.

Bennett, Jane (2010). Vibrant matter: A political ecology of things. Duke University Press.

Braidotti, Rosi (1991). Patterns of dissonance: A study of women in contemporary philosophy (E. Guild., Trans.). Polity Press.

Braidotti, Rosi (2002). Metamorphoses: Towards a materialist theory of becoming. Polity Press. 
Braidotti, Rosi (2006). Transpositions: On nomadic ethics. Polity Press.

Braidotti, Rosi (2011). Nomadic subjects: Embodiment and sexual difference in contemporary feminist theory (2nd ed.). Columbia University Press.

Braidotti, Rosi (2012). Interview with Rosi Braidotti. In R. Dolphijn \& I. van der Tuin, (Eds.), New materialism: Interviews \& cartographies (pp. 19-37). Open Humanities Press. An Imprint of MPublishing-University of Michigan Library.

Braidotti, Rosi (2013). The Posthuman. Polity Press.

Carstens, Delphi (2019). New materialist perspectives for pedagogies in times of movement, crisis and change. Alternation, 26(2), 138-160. https://doi.org/10.29086/2519-5476/2019/v26n2a7.

Carstens, Delphi (2020). Toward a pedagogy of speculative fabulation. CriSTal: Critical Studies in Teaching and Learning, 8(SI), 75-90. https://www.ajol.info/index.php/cristal/article/view/200712.

Chen, Mel Y. (2012). Animacies: Biopolitics, racial mattering, and queer affect. Duke University Press.

Cooper, Melinda (2008). Life as surplus: Biotechnology and capitalism in the neoliberal era. University of Washington Press.

DeLanda, Manuel (2002). Intensive science and virtual philosophy. Bloomsbury.

Deleuze, Gilles (1994). Difference and repetition (P. Patton, Trans.). Columbia University Press. Originally published in French 1968.

Deleuze, Gilles (2006). Two regimes of madness: Texts and Interviews 1975-1995(A. Hodges and M. Taormina, Trans. \& D. Lapoujade, Ed.). Semiotext(e).

Deleuze, Gilles \& Guattari, Félix (1983). Anti-Oedipus: Capitalism and schizophrenia (R. Hurley, M. Seem \& Lane. H, Trans). University of Minnesota Press. Originally published in French 1972.

Deleuze, Gilles \& Guattari, Félix (1987). A thousand plateaus: Capitalism and schizophrenia (B. Massumi, Trans.). University of Minnesota Press. Originally published in French 1980.

Derrida, Jacques (1994). Specters of Marx: The state of the debt, the work of mourning and the New International (P. Kamuf, Trans. \& B. Magnus and S. Cullenberg, Intr.). Routledge.

Ferreira da Silva, Denise (2017). 1 (life) $\div 0$ (blackness) $=\infty-\infty$ or $\infty / \infty$ : On matter beyond the equation of value. e-flux, 79(February). Retrieved from https://www.eflux.com/journal/79/94686/1-life-0-blackness-or-on-matter-beyond-the-equation-ofvalue/. 
Fisher, Mark (2009). Capitalist realism: Is there no alternative? Zero books.

Freire, Paulo (2006). Pedagogy of the oppressed (M. Bergman Ramos, Trans. \& D. Macedo, Intr.). Continuum.

Geerts, Evelien, \& van der Tuin, Iris (2016, 27 July). Diffraction \& reading diffractively. New Materialism Almanac. Retrieved from: http://newmaterialism.eu/almanac/d/diffraction. Republished in this special issue.

Geerts, Evelien \& Carstens, Delphi (2019). Ethico-onto-epistemology. Philosophy Today, 63(4), 915-925. https://doi.org/10.5840/philtoday202019301.

Grosz, Elizabeth (2017). Incorporeal: Ontology, ethics, and the limits of materialism. Columbia University Press.

Guattari, Félix (2000). The three ecologies (I. Pindar and P. Sutton, Trans.). Continuum. Originally published in French in 1989.

Haraway, Donna J. (1997). Modest_witness@second_millenium: FemaleMan@_meets_Oncomouse ${ }^{\mathrm{TM}}$. Feminism and technoscience. Routledge.

Haraway, Donna J. (2016). Staying with the trouble: Making kin in the Chthulucene. Duke University Press.

Hayles, Katherine (2017). Unthought: The power of the cognitive nonconscious. University of Chicago Press.

hooks, bell (1994). Teaching to transgress: Education as the practice of freedom. Routledge.

Hunt, Sarah (2014). Ontologies of Indigeneity: The politics of embodying a concept. Cultural geographies, 21(1), 27-32. https://doi.org/10.1177/1474474013500226.

Jackson, Zakiyyah Iman (2020). Becoming human: Matter and meaning in an antiblack world. New York University Press.

Koro-Ljungberg, Mirka (2015). Reconceptualizing qualitative research: Methodologies without methodology. Sage Publications.

Levinas, Emmanuel (2015). Totality and infinity: An essay on exteriority (A. Lingis, Trans.). Kluwer Academic Publishers.

Manning, Erin (2009). Relationscapes: Movement, art, philosophy. MIT Press.

Minh-ha, Trinh T. (1997). Not you/like you: Postcolonial women and the interlocking questions of identity and difference. In A. McClintock, A. Mufti, and E. Shohat (Eds.), Dangerous liaisons: Gender, nation, and postcolonial perspectives (pp. 415-149). University of Minnesota Press.

Morton, Timothy (2018). Being ecological. MIT Press. 
Povinelli, Elizabeth (2016). Geontologies: A requiem for late liberalism. Duke University Press.

Puig de la Bellacasa, María (2017). Matters of care: Speculative ethics in more than human worlds. The University of Minnesota Press.

Ramey, Joshua (2013). Learning the uncanny. In D. Masny \& I. Semetsky (Eds), Deleuze and education (pp. 177-195). Edinburgh University Press.

Sauvagnargues, Anne (2019). The wasp and the orchid: On multiplicities and becomology. In P. de Assis \& P. Giudici (Eds.), Aberrant nuptials: Deleuze and artistic research (pp.177-182). Leuven University Press.

Shotwell, Alexis (2016). Against purity: Living ethically in compromised times. The University of Minnesota Press.

Simondon, Gilbert (2017). On the mode of existence of technical objects (C. Malaspina \& J. Rogove, Trans.). University of Minnesota Press.

Simondon, Gilbert (2020). Individuation in light of notions of form and information (T. Adkins, Trans.). University of Minnesota Press.

Smith, Linda Tuhiwai (2013). Decolonizing methodologies: Research and Indigenous peoples. Zed Books.

Stoker, Bram (1897). Dracula. Archibald Constable and Company.

TallBear, Kim (2014). Standing with and speaking as faith: A feminist-Indigenous approach to inquiry. Journal of Research Practice, 10(2), 1-7. Retrieved from http://irp.icaap.org/index.php/irp/article/view/405/371.

Todd, Zoe (2016). An Indigenous feminist's take on the ontological turn: "Ontology" is just another word for colonialism. Journal of Historical Sociology, 29(1), 4-22. https://doi.org/10.1111/johs.12124.

Weheliye, Alexander G. (2014). Habeas viscus: Racializing assemblages, biopolitics, and Black feminist theories of the human. Duke University Press.

\section{Author information}

\section{Chantelle Gray (gray.chantelle@gmail.com)}

Chantelle Gray (PhD) is an Associate Professor in the School of Philosophy at NorthWest University, South Africa. Her research interests include Continental Philosophy, queer theory, music studies, and literary and film studies, although she specialises in Deleuzoguattarian philosophy. She is the co-convener of the biennial South African Deleuze \& Guattari Studies Conference (www.deleuzeguattari.co.za) and serves on the editorial boards of Somatechnics and Stilet. Her books include Deleuze and 
Anarchism, co-edited with Aragorn Eloff (2019, Edinburgh University Press) and she is currently working on a monograph entitled Anarchism after Deleuze and Guattari: Folding Cosmologies.

\section{Delphi Carstens (carstensdelphi@gmail.com)}

Delphi Carstens is a lecturer at the University of the Western Cape. He holds a Ph.D. (in apocalyptic science fictional literature and philosophy) from Stellenbosch University. His research interests and publications include the Anthropocene/Capitalocene, Deleuzoguattarian pedagogical interventions, uncanny science fictions, and sorcerous new materialisms. His publications include, amongst others, chapters in edited volumes by Palgrave, Sternberg, Bloomsbury and Taylor and Francis. as well as journal articles in The South African Journal of Higher Education (SAJHE), Education as Change, Alternation, CriSTal, Parallax, and Somatechnics.

\section{Evelien Geerts (e.m.l.geerts@bham.ac.uk)}

Evelien Geerts is a multidisciplinary philosopher and Research Fellow at the University of Birmingham, where she is working on the ERC-funded Urban Terrorism in Europe (2004-19): Remembering, Imagining, and Anticipating Violence project. She holds a Ph.D. in Feminist Studies and History of Consciousness (DE) from the University of California, Santa Cruz. Her research interests include new materialisms \& Deleuzoguattarian philosophy, critical epistemologies, political philosophical questions of identity, difference, and violence, and critical and diffractive pedagogies. She previously has published in Philosophy Today, Women's Studies International Forum, and Rhizomes: Cultural Studies in Emerging Knowledge-publications that can be found at www.eveliengeerts.com-and is a Posthumanities Hub affiliated researcher plus a PhEMaterialisms member.

\section{Aragorn Eloff (aragorn@newframe.com)}

Aragorn Eloff an independent researcher with a long-standing interest in the work of Gilles Deleuze and Félix Guattari, and one of the conveners of the biennial South 
African Deleuze \& Guattari Studies Conference (www.deleuzeguattari.co.za). He is also a co-founder of the Institute for Critical Animal Studies in Africa (www.criticalanimalstudies.org/icas-africa/). His recent work focuses on the application of Deleuze and Guattari's thought to questions around radical politics (specifically anarchism), subjectivity and Earth/animal liberation, and he is currently busy with a research project applying Deleuze's late work on control societies to contemporary forms of algorithmic governance and reason. Aragorn also works in the field of experimental music philosophy and performance; his work with generative and gestural composition can be explored at www.further.co.za. 